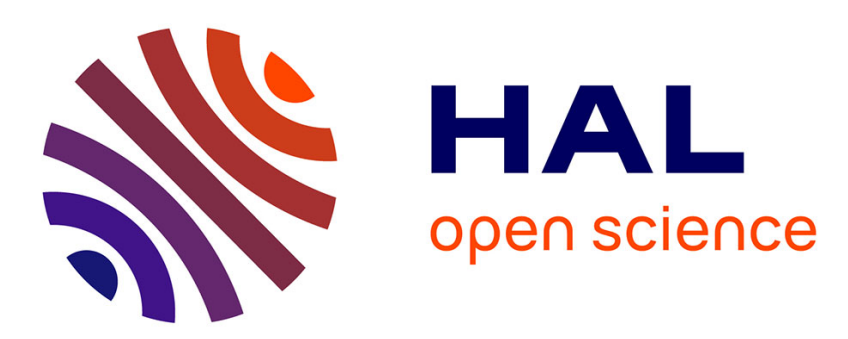

\title{
Vulnerability, Trade, Financial Flows and State Failure in Small Island Developing States
}

Mark Mcgillivray, Wim Naudé, Amelia Santos-Paulino

\section{To cite this version:}

Mark Mcgillivray, Wim Naudé, Amelia Santos-Paulino. Vulnerability, Trade, Financial Flows and State Failure in Small Island Developing States. The Journal of Development Studies, 2010, 46 (05), pp.815-827. 10.1080/00220381003623822 . hal-00594796

\section{HAL Id: hal-00594796 https://hal.science/hal-00594796}

Submitted on 21 May 2011

HAL is a multi-disciplinary open access archive for the deposit and dissemination of scientific research documents, whether they are published or not. The documents may come from teaching and research institutions in France or abroad, or from public or private research centers.
L'archive ouverte pluridisciplinaire HAL, est destinée au dépôt et à la diffusion de documents scientifiques de niveau recherche, publiés ou non, émanant des établissements d'enseignement et de recherche français ou étrangers, des laboratoires publics ou privés. 


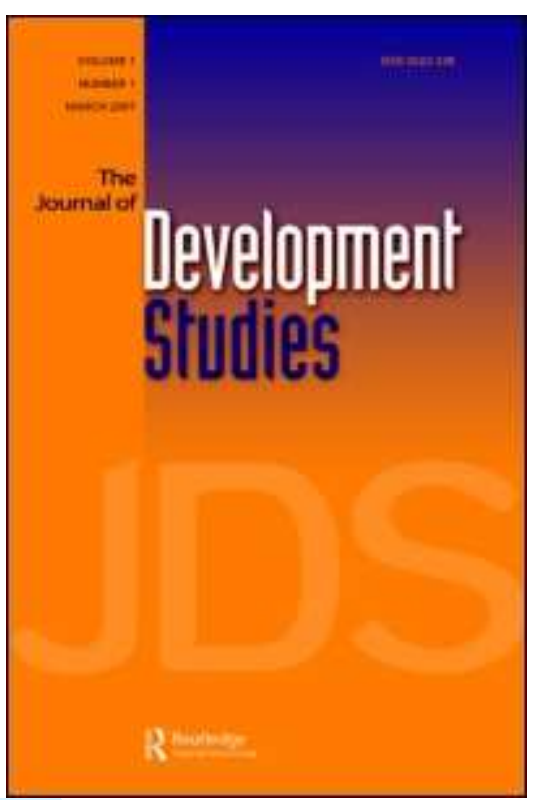

Vulnerability, Trade, Financial Flows and State Failure in Small Island Developing States

\begin{tabular}{|r|l|}
\hline Journal: & Journal of Development Studies \\
\hline Manuscript ID: & FJDS-2009-Nov-0044.R1 \\
\hline Manuscript Type: & Papers in Special Issues \\
\hline Keywords: & $\begin{array}{l}\text { Foreign aid < Economics, Economic development < Economics, } \\
\text { Vulnerability < Social Issues, Trade < Economics, Caribbean }< \\
\text { Geographical Area, Asia Pacific < Geographical Area }\end{array}$ \\
\hline \multicolumn{2}{|c}{} \\
\hline
\end{tabular}

\section{(5) ScholaroNE \\ Manuscript Central}




\title{
Vulnerability, Trade, Financial Flows and State Failure in Small Island Developing States
}

\begin{abstract}
Small Island Developing States (SIDS) are very different to other developing countries. Relative to GDP they have the highest levels of foreign trade and aid receipts of all developing countries. Remittances from abroad are a far more important source of income for SIDS, and some depend very heavily on export revenues. The quality of governance varies tremendously among SIDS, they are over-represented among countries classified as fragile states and many are prone to state failure. These and other factors combine to make SIDS highly vulnerable to external economic shocks. Achieving development in SIDS is as a consequence an especially complex task that requires an understanding of the roles played by aid, trade, remittances and governance in these countries. This paper looks at these issues, along with providing various stylized facts about SIDS. In so doing it serves a background and broad contextual setting for the papers that follow in this Special Issue on 'Achieving Development in Small Island Developing States'.
\end{abstract}

Key words: Small island developing states, vulnerability, foreign aid, remittances.

JEL Classification numbers: D74, F2, F5, F35, F43, 057. 


\section{Vulnerability, Trade, Financial Flows and State Failure in Small Island Developing States}

\section{Introduction}

The United Nations currently classifies 52 countries and territories as Small Island Developing States (SIDS). More than 50 million people live in these countries. Fortythree of these countries are located in the Caribbean and the Pacific regions. SIDS is a diverse group in a number respects. It includes countries that are relatively rich by developing country standards, such as Singapore and Bahamas, but also some of the poorest countries in the world, including Comoros and Timor-Leste. ${ }^{1}$

All SIDS are vulnerable to economic shocks and natural hazards to a degree that few other countries or regions are (Attz, 2009, Heger, et al., 2009, McGillivray, et al. 2008, Naudé et al., 2009a, 2009b). ${ }^{1}$ This is generally not compensated for by sufficient state or household resilience (Chowdhury, 2009). Relative to GDP they receive the highest levels of foreign aid of all developing countries, remittances from abroad are a very important source of income and some depend very heavily on export revenues. The quality of governance varies tremendously among SIDS and many are prone to state failure. These and other factors combine to make SIDS highly vulnerable to external economic shocks and especially susceptible to natural disasters, including tsunamis, and climate change.

It follows that achieving and sustaining development in SIDS is a complex and demanding tasks. Among its prerequisites is an understanding of the roles played by aid,

\footnotetext{
${ }^{1}$ Singapore - an export dependent SIDS - despite being a global financial and manufacturing hub, is also vulnerable external economic shocks. The country was particularly affected by the global financial recession and collapse in world trade, experiencing a decline in GDP growth rates during 2008-2009 (ADB, 2009).
} 
trade, remittances and governance. What is the impact of aid on growth and related outcomes? How should aid be allocated among SIDS? What are the impacts of trade shocks on current account balances? What drives remittances to SIDS and what are their macroeconomic impacts? What is the relevance of governance to growth in SIDS and what are the costs of state failure in them? These issues are addressed in the papers that follow in this Special Issue. This paper provides a broad background contextualization, providing a case as to why SIDS should be seen as especially vulnerable to external shocks, and why aid, trade, remittances and governance are dominant issues in development in these countries. It does this by providing stylized facts on these and other variables for SIDS and other developing countries.

This paper consists of three more sections. Section 2 provides some stylized facts on SIDS and other developing countries. Section 3 provides an overview of the papers that follow in the Special Issue. Section 4 briefly concludes.

\section{SIDS: A Development Profile}

Most countries in the SIDS classification of UN are islands, developing countries and have sufficiently small populations to be classified as a SID. They differ, however, in a number of respects. As mentioned, they differ in terms of material living standards, measured by GDP per capita. GDP per capita, as shown in Appendix Table A2, ranges from \$US28000 in Singapore to only \$US369 in the Comoros. Human development outcomes, including those in health and education also vary substantially (UNDP, 2009). Yet, as relatively small economies they have much in common. The most central unifying feature is that due to their smallness they need far more than other economies to look 
beyond their own borders to drive economic growth and development. Prior to examining this feature of SIDS let us first look at their growth performance relative to other countries.

The SIDS group of countries has maintained a reasonable rate of real GDP growth in recent decades. As is shown in Table 1 and Figure 1, they have achieved an average annual yearly growth rate of real GDP over the period 1985 to 2007 of 3.3 percent. ${ }^{2}$ All countries in the developed country (DC) and least developed country (LDC) groups have performed a little better over the same period, recording rates of real GDP or 4.2 and 4.1 percent, respectively.

There is considerable variation in growth rates among SIDS, however, as Table 1 and Figure 2 reveal. This reinforces the point about heterogeneity within the group. Of all country groups shown, SIDS located in the Pacific region record the lowest average and by far the most volatile GDP growth for the period under consideration. Pacific SIDS growth rates range from 2.0 to 9.1 percent and the volatility, as measured by the coefficient of variation shown in Table 1, is more than twice that of all developing countries and the SIDS group as a whole. Volatility in GDP growth rates is also higher in SIDS located in Africa and the Caribbean, respectively, than in all developed countries. 
Figure 1: Real GDP Growth, 1985 to 2007

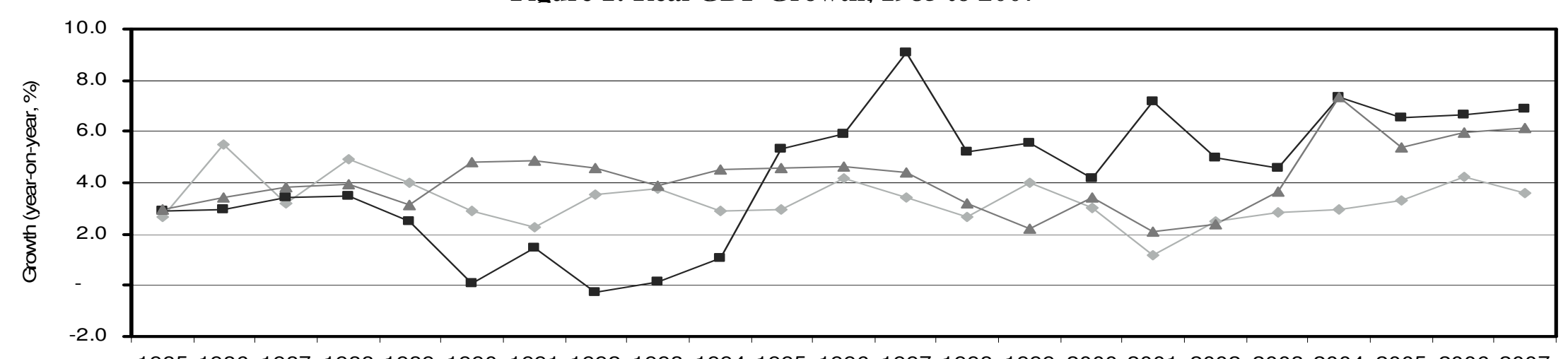

19851986198719881989199019911992199319941995199619971998199920002001200220032004200520062007 $\multimap$ SIDS $\because$ LDC $\longleftarrow$ DC

Source: constructed from data in World Bank (2009a)

Figure 2: SIDS Real GDP Growth by Region, 1985 to 2007

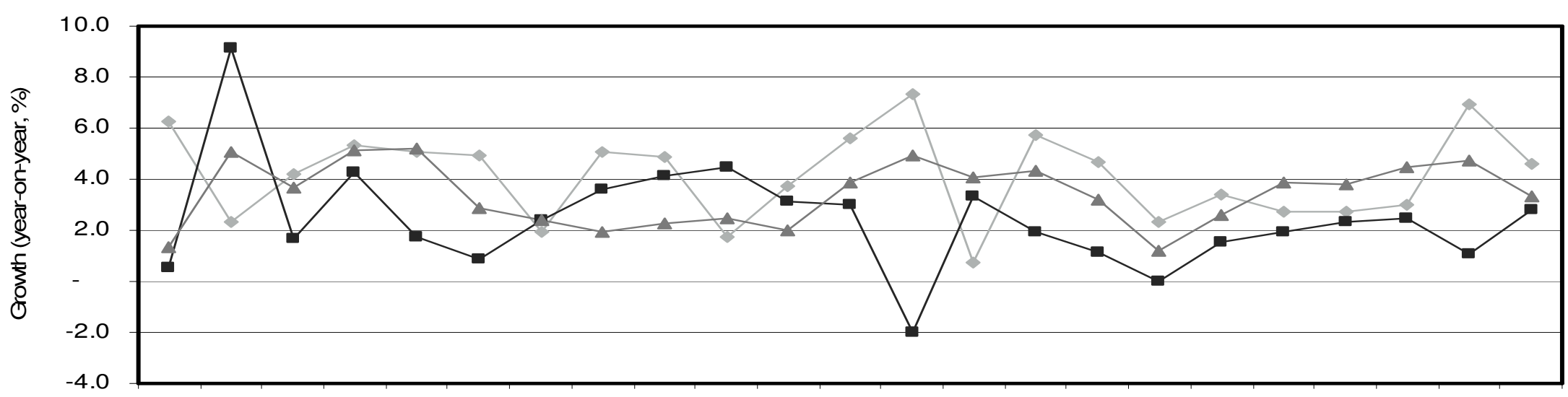

19851986198719881989199019911992199319941995199619971998199920002001200220032004200520062007 $\longrightarrow$ Africa $\longrightarrow$ Pacific $\multimap$ Caribbean

Source: constructed from data in World Bank (2009a) 
Table 1: Real GDP Growth Descriptive Statistics, 1985 to 2007

\begin{tabular}{|c|cccc}
\hline Country Group & Minimum & Maximum & Average & $\begin{array}{c}\text { Coefficient of } \\
\text { Variation }\end{array}$ \\
\hline Small Island Developing States & 1.2 & 5.5 & 3.3 & 0.27 \\
\cline { 1 - 4 } African SIDS & 0.7 & 7.4 & 4.1 & 0.42 \\
\hline Pacific SIDS & 2.0 & 9.1 & 2.4 & 0.86 \\
\hline Caribbean SIDS & 1.2 & 5.2 & 3.4 & 0.36 \\
\hline Least Developed Countries & 0.3 & 9.1 & 4.2 & 0.61 \\
All Developing Countries & 2.1 & 7.4 & 4.1 & 0.31 \\
\hline
\end{tabular}

Source: calculated from data in World Bank (2009a).

Let us now go behind the GDP numbers and look at some of their drivers. It is well known that SIDS rely heavily on trade to drive growth. Heger et al. (2009) for instance show that in the Caribbean a single commodity accounts for an average of 45 per cent of exports, and the top five export commodities for between 70 per cent and 96 per cent of countries' exports. This creates economic vulnerability to changes in export demand and commodity prices.

Figure 3 and Table 1 show that trade flows, expressed as the sum of commodity exports and imports relative to GDP, are far higher in SIDS than in all other DCs and the LDC group over the entire period 1980 to 2007. Commodity exports and imports as a percentage of GDP in any one year were no less than 95 and as high as 141 per cent, and averaged 110 per cent for the entire period. The equivalent numbers for all developing countries were 64, 94 and 78 per cent, respectively. For the LDC group they are 49, 77 and 59 per cent, respectively. More pertinent is volatility in trade given its implications for vulnerability to external shocks. As Table 2 shows, SIDS trade is more volatile than for other developing countries. The coefficient of variation for SIDS trade relative to GDP for the period 1980 to 2007 is 10.23 , compared that those for the all DCs and the LDC group, 
Figure 3: Trade Flows, 1985 to 2007

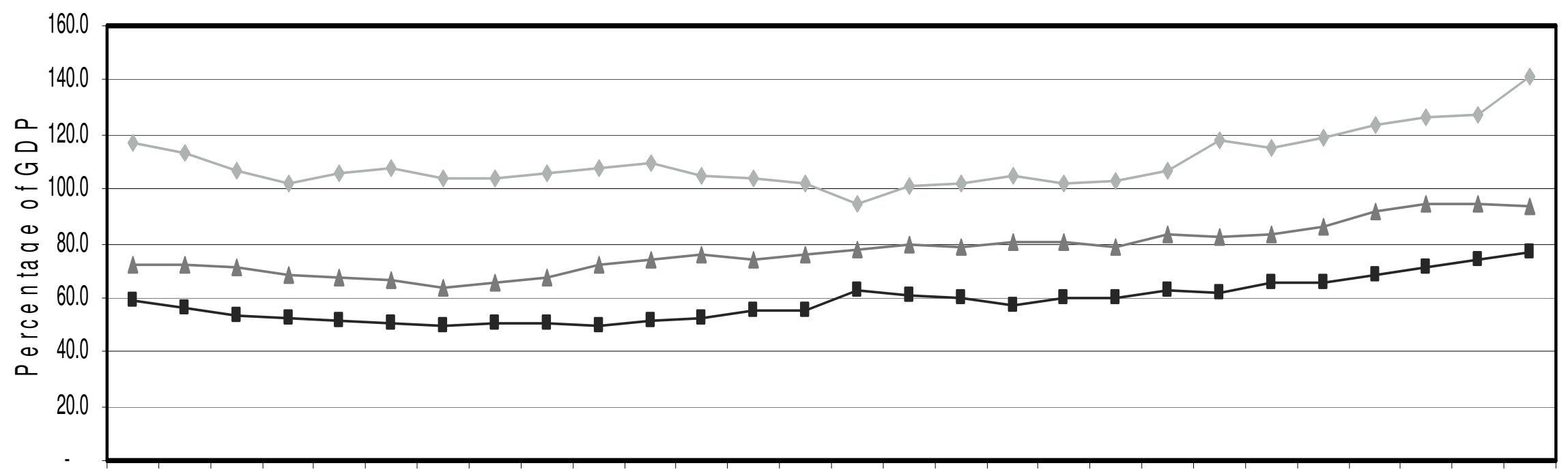

$19801981198219831984198519861987198819891990199119921993 \quad 19941995199619971998199920002001200220032004200520062007$

$$
\rightarrow-S I D S \rightarrow L D C \multimap-D C
$$

Source: constructed using data in World Bank (2009a). 
Table 2: Trade Flow Descriptive Statistics, 1980 to 2007

\begin{tabular}{|lcccc}
\hline Country Group & Minimum & Maximum & Average & $\begin{array}{c}\text { Coefficient of } \\
\text { Variation }\end{array}$ \\
\hline Small Island Developing States & 94.5 & 141.4 & 110.0 & 10.23 \\
Least Developed Countries & 49.3 & 77.0 & 58.7 & 7.56 \\
All Developing Countries & 63.9 & 94.3 & 77.5 & 8.80 \\
\hline
\end{tabular}

Source: calculated from data in World Bank (2009a).

Figure 4: Destination of Pacific Island Countries and Timor-Leste Exports, 2007.

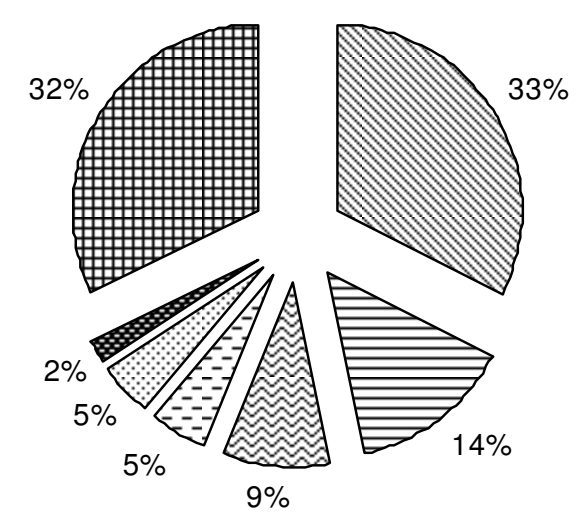

$\checkmark$ Australia $\boxminus$ Japan $\square$ China $\square$ Germany $⿴$ United States of America $\mathbf{m}$ New Zealand $\boxplus$ Other

Source: AusAID (2009).

of 7.56 and 8.80, respectively. It is little wonder, therefore, that SIDS growth is more volatile than for these other groups of countries.

Trade related volatility will be a function of a number of variations, in addition to the level of trade relative to a country's GDP and concentration of commodities exported. It will also depend, one would expect, on the extent of concentration of export markets. Figure 4 shows the destination of commodity exports of Pacific Island countries and Timor-Leste, each of which are SIDS, for 2007. More than half of all exports of these SIDS go to three countries only. One-third goes to a single country, Australia. By relying 
on such a small number of exports markets these SIDS are clearly very vulnerable to economic down-turn in one or more of them.

Perhaps more striking are data on aid and private remittances to SIDS. These flows are most unlike trade in that they do not result from commercial activity. They result from conscious decisions of foreign donor governments and private overseas citizens to transfer resources to SIDS. Many SIDS very heavily rely on these transfers, more so than other countries. SIDS citizens look heavily to overseas labour markets. Those finding employment abroad send often relatively large amounts of money to relatives living at home and foreign governments provide extremely large amounts of official development assistance to SIDS.

The preceding points are substantiated by Figure 5, which shows levels of official development assistance (aid), private remittances and foreign direct investment (FDI). Aid to SIDS during the period 1980 to 2006 was the equivalent of 16 per cent of GDPs, compared to only one per cent on average for all other developing countries. Private remittances from abroad to the former group of countries are the equivalent of eight per cent of GDP during this period, while for the latter they are three per cent. Remittances and aid to the LDC group were the equivalent of nine and six per cent of GDP, respectively, during 1980 to 2006. 
Figure 5: Aid, Remittances and FDI, 1980 to 2006

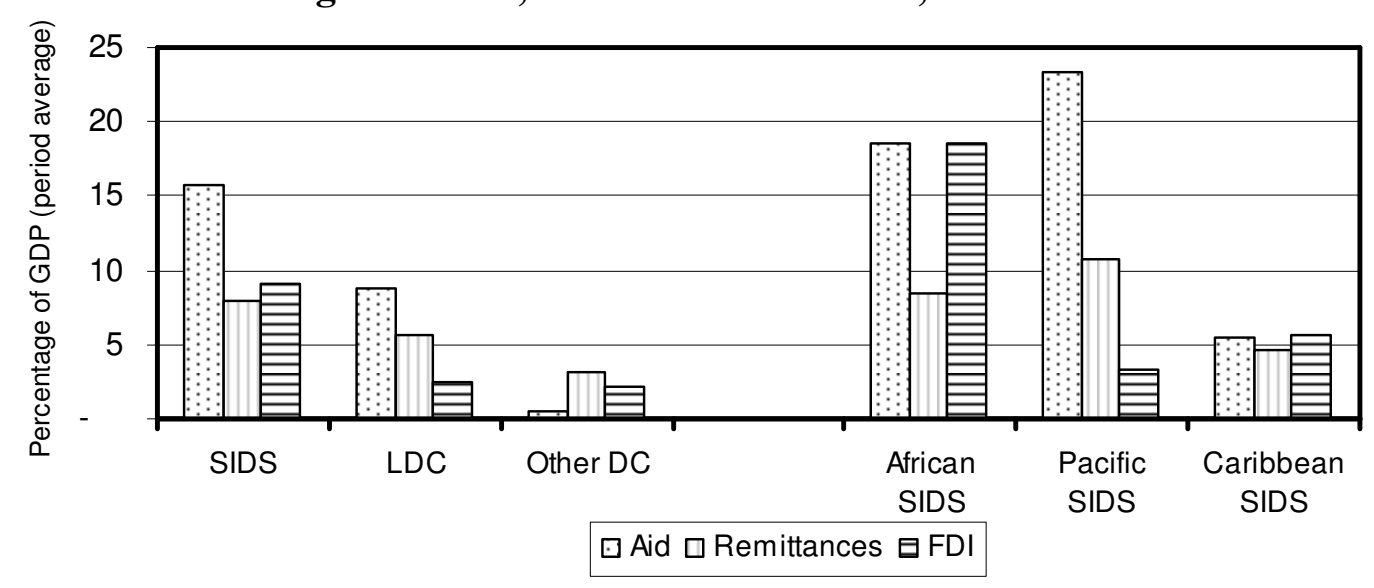

Source: constructed using data in World Bank (2009a).

There is considerable variation within the SIDS group in terms of aid, remittance and FDI flows. SIDS in the Pacific receive very large amounts of aid and remittances and low amounts of FDI relative to GDP. Aid and remittances to these countries are indeed far higher, at the equivalent of 23 and 11 per cent of GDP, respectively. African SIDS observe higher levels of FDI relative to GDP, at 19 per cent, than the other groups of SIDS. The Caribbean SIDS depend less on aid, remittances and FDI, with these flows being no higher than the equivalent of six per cent of GDP. Figure 6 reinforces just how important quantitatively remittances are to Pacific Islands, relative to others. It shows the ten remittance receiving countries in the world, when these inflows are measured as a percentage equivalent of GDP. Two of these countries are SIDS located in the Pacific, Tonga and Samoa. Remittances to these countries are the equivalent of just under 44 and 23 per cent of GDP, respectively. 
Figure 6: Remittances to Top Ten Receiving Countries, 2007

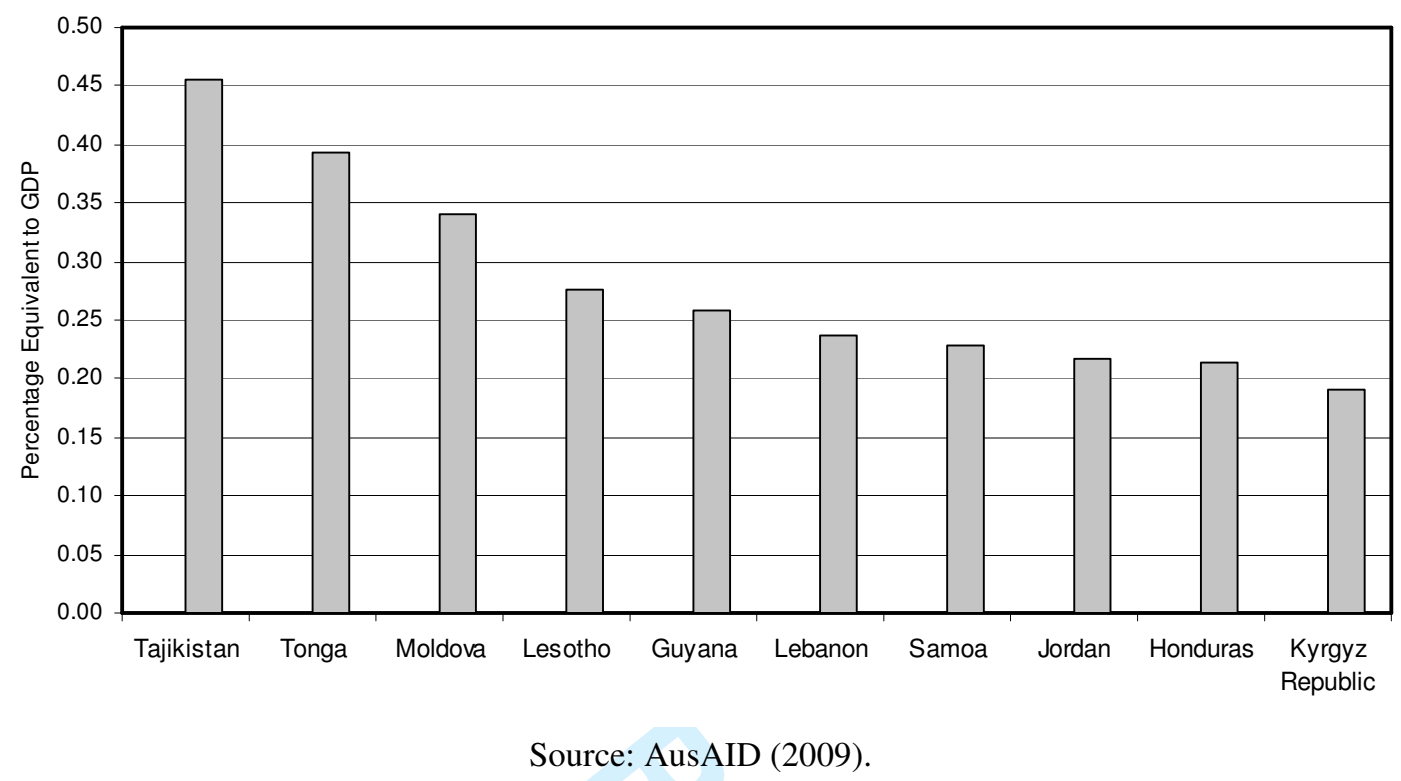

Good governance has been shown time and time again in empirical studies to be a robust determinant of economic growth. There is also some empirical evidence, and a widespread belief in aid donor circles that governance is an important determinant of aid effectiveness. It is also reasonable to expect that building resilience to external shocks will crucially depend on the quality of governance in SIDS. The information in Table 3 should therefore be of concern.

The donor community for a number of years considered a state to be fragile if its World Bank Country Policy and Institution Assessment (CPIA) score was critically low. Two CPIA thresholds were used. One corresponded to a score that would put a country in the bottom two CPIA quintiles in the year in question. Another classified a country as fragile if it had a CPIA score of 3.0 or less (Branchflower et al. 2004, McGillivray 2006 and Feeny and McGillivray, 2009). This criterion is also used by the World Bank to classify a 
nation as low income country under stress (LICUS). The World Bank (2009b) publishes CPIA scores for countries that receive aid grants from its International Development Association (IDA). As Table 3 shows there were between 75 and 77 of these recipients between 2005 and 2008. Between 21 and 24 per cent of these countries were SIDS. While SIDS during these years typically had only slightly lower overall average CPIA scores than other IDA countries, they are over-represented in the fragile state category countries. That is, while between 21 and 24 per cent of IDA recipient countries were SIDS, SIDS constitute between 27 and 35 per cent of recipients that are fragile according to the above classification criteria.

Table 3: Policy and Institutional Performance Assessments

\begin{tabular}{lcccc}
\hline & 2005 & 2006 & 2007 & 2008 \\
\hline Number of IDA Recipient Countries & 76 & 77 & 75 & 76 \\
Proportion of IDA Countries that are SIDS (\%) & 21 & 23 & 24 & 24 \\
$\begin{array}{l}\text { Proportion of SIDS in Bottom Two CPIA Score } \\
\text { Quintiles (\%) }\end{array}$ & 30 & 33 & 27 & 30 \\
$\begin{array}{l}\text { Proportion of SIDS with CPIA Score of 3.0 or } \\
\text { less (\%) }\end{array}$ & 30 & 33 & 35 & 35 \\
Average CPIA Score - SIDS & 3.34 & 3.27 & 3.29 & 3.30 \\
Average CPIA Score - All other IDA Countries & 3.33 & 3.32 & 3.22 & 3.33 \\
\hline \multicolumn{4}{l}{ Source: calculated from data in World Bank (2009b). }
\end{tabular}

\section{Special Issue Overview}

This Special Issue contains further seven papers. The first is 'Assessing the Economic Vulnerability of Small Island Developing States and the Least Developed Countries' by Patrick Guillaumont. Guillaumont considers three questions that in subsequent papers underlie various more specific concerns with aid, trade, remittances and state failure in SIDS. These relate to why vulnerability matters for development in SIDS, how economic vulnerability is to be measured and the implications of measuring economic vulnerability for the allocation of aid. Guillaumont provides answers to these questions by analyzing 
the situation in SIDS in relation to the broader LDC category. A basic premise of the paper is that aid dampens the negative effects of vulnerability on growth and aid is more effective in vulnerable countries such as the SIDS. In support of the comments made above about the vulnerability of SIDS, Guillaumont finds that on the basis of Economic Vulnerability Index (EVI) values vulnerability is higher in SIDS than in LDCs and that SIDS and LDCs are more economically vulnerable than other developing countries. He does, however, find that EVI values for SIDS are diminishing over time.

The third paper, 'Terms of Trade Shocks and the Current Account in Small Island States' by Amelia U. Santos-Paulino, explores deeper into one of the most fundamental causes of economic vulnerability in SIDS, export instability. Santos-Paulino focuses on how shocks to the terms of trade impact on their current account balances. Using a panel data vector autoregression (VAR) modelling approach, Santos-Paulino proceeds to quantify the impact of terms of trade changes on the current account in a sample of 14 SIDS. She finds that these have a negative impact on current account balances and real output. The current account does recover after a lag, suggesting a J-curve type reaction of current account balances to adverse terms of trade shocks. Finally, Santos Paulino considers the policy implications of this finding, pointing to the importance of strengthening initiatives such as the IMF's Compensatory Financing Facility, and the Stabex Scheme under the Lomé (and Cotonou) conventions (relating to aid issues also discussed by Guillaumont).

The fourth paper, 'The Short Run Macroeconomic Impact of Foreign Aid to Small States' by Henrik Hansen and Derek Heady, is the first of three looking intensively at foreign aid to SIDS. The paper applies a VAR modelling approach to explain the short-run macroeconomic responses to unexpected aid shocks. A key issue addressed is the 
observed volatility and smoothing of aid, and how this relates to absorptive capacity and spending, and the need for prudential policy decisions in the recipient economy. The study reports that aid dependent countries typically appear to smooth aid receipts, which is important to mitigate contemporaneous shortfalls in foreign assistance and other flows such as export earnings. Again, this reiterates a core message evident in the previous two papers.

The fifth paper, 'Aid and Growth in Small Island Developing States'by Simon Feeny and Mark McGillivray, examines the impact of aid on real per capita income growth in SIDS. Various econometric procedures are employed. The results suggest that foreign assistance is effective at fostering economic growth in SIDS but with diminishing returns. The paper also finds some evidence that foreign aid is less effective in SIDS that can be considered as highly fragile (namely, those in the bottom CPIA quintile), and that these countries face greater absorptive capacity constraints. It finds no evidence that the impact of aid on growth in SIDS is contingent on the quality of their policies and the performance of their institutions, except for those countries that are fragile, as fragility is effectively measured in governance terms through the CPIA. Since there seem to be diminishing returns in the impact of aid on growth in SIDS, meaning that the marginal effect of aid on growth falls as aid exceeds a given level, Feeny and McGillivray also consider whether aid volumes to SIDS are appropriate from a growth efficiency perspective. They find that while some SIDS receive far more aid than would be justified on a growth perspective, there is some scope for increases in aid to SIDS as a group.

The impact of aid on the macroeconomy is further examined in 'Aid and Dutch Disease in the South Pacific' by David Fielding. A weakness of studies looking at the impact of 
aid on growth is that they typically cannot tell us why aid might have had a particular impact on growth. As such one is left to speculate as to the processes or channels through which aid might influence growth. Fielding's study in part compensates for this by looking at whether aid can lead to an appreciation of the real exchange rate in SIDS, i.e. whether it induced Dutch Disease effects. There are strong a priori grounds for expecting that aid to SIDS, especially those in Pacific, might have Dutch Disease impacts given the level of these inflows relative to GDP. Fielding uses VAR modelling techniques to address this question. Results suggest that, on average, a relatively closed middle-income economy with inefficient government is more likely to suffer from Dutch Disease effects of aid. Combined with the results obtained by Feeny and McGillivray, this suggests that real exchange rate appreciations have offset to some extent the positive impact of aid on growth in some SIDS.

The seventh paper is 'Remittances and the Macroeconomy: The Case of Small Island Developing States' by Catalina Amuedo-Dorantes, Susan Pozo and Carlos Vargas-Silva. The paper is concerned with the impacts of natural disasters and foreign development aid on remittances to SIDS and the impact of remittances on the real exchange rates of these countries. The authors use a VAR econometric modelling approach and data for 19 SIDS to analysis these impacts. They find that a natural disaster in SIDS is associated with higher levels of remittances to these countries. The paper's finding for the link between aid and remittances are particularly interesting. Aid donors do not seem to allocate aid on the basis of the level of remittances received by SIDS. As such these donors neither treat aid a substitute nor complement to remittances. The providers of remittances however seem to treat these flows as a substitute for aid, by granting lower levels of remittances 
than would otherwise be the case when aid increases and higher levels than would otherwise be the case when aid decreases. Amuedo-Dorantes et al. find no evidence of an association between remittances and the real exchange rate in the sample of SIDS under consideration.

The final paper is 'Paradise Lost: the Cost of State Failure in the Pacific' by Lisa Chauvet, Paul Collier and Anke Hoeffler. . It was pointed out above that SIDS are over represented among IDA recipients in the fragile state groups. Chauvet et al. attempt to quantify the cost of state failure among Pacific Island SIDS, defining a 'failing state' as one that is assigned to the above-mentioned LICUS group for at least four years continuously. They distinguish between three costs of state failure defined in this way: (i) the costs to the citizens in terms of poor policies and governance; (ii) the costs to the citizens in terms of conflict and uncertainty; and (iii) the (spillover) costs on their neighbours due to poor policies and conflict. As the authors note, because SIDS are islands there are less spillover effects, but the countries affected suffer more given that their openness will exacerbate the flight of capital and skilled labour. Thus, compared to other fragile states (where the major costs are those imposed on neighbours), the costs of state failure in SIDS is almost totally borne by the country itself. In this context, it follows that any possible case for intervention rests on humanitarian criteria rather than on protecting the interests of the other countries in the Pacific region.

Overall, the papers show that policy and institutional performances in SIDS are correlated with other aspects of vulnerability. Hence, development outcomes are affected by both the intrinsic institutional constrains and resources endowments, alongside to the international dimensions of vulnerability, channeled by trade, finance and migration. A 
number of studies look at aid-exchange rate and/or aid-growth relationships, and although the results can be generalized for SIDS and other fragile developing states, some are related to specific areas like the South Pacific. For instance, Fielding's results regarding the impact of aid on the macroeconomy discussed above could be interpreted as more negative than others (e.g. Hansen and Heady's, and Feeney and McGillivray's). This can be attributed to different specifications or approaches to a relationship and/or samples.

\section{Conclusion}

This paper has provided a profile of Small Island Developing States (SIDS). It has pointed out that largely owing to their smallness, SIDS have to rely very heavily on factors beyond their borders to drive growth, in particular exports, aid and remittances. The paper also pointed out that the quality of governance varies tremendously among SIDS, they are over-represented among countries classified as fragile states and many are prone to state failure.

The paper also provided a background and broad contextual setting for the papers that follow in this Special Issue on 'Achieving Development in Small Island Developing States'. The topics covered in this Special Issue provide a useful illustration of the type of research that can be conducted on SIDS. More research on these countries is certainly warranted given the huge challenges they face. Hopefully this Special Issue will stimulate that research. 


\section{References}

Asian Development Bank (2009), Asian Development Outlook 2009 Update, Chapters I and II, Manila: Philippines.

Australian Agency for International Development (AusAID) (2009), Pacific Economic Survey 2009, Canberra: Australian Agency for International Development.

Attz, M. (2009). 'Natural Disasters and Remittances: Poverty, Gender and Disaster Vulnerability in Caribbean SIDS', (In Naudé, W, A.U. Santos-Paulino and M. McGillivray eds. Vulnerability in Developing Countries. Tokyo and New York: UNU Press. Pp. 249-261.)

Branchflower, A., S. Hennell, S. Pongracz and M. Smart (2004), How Important are Difficult Environments to Achieving the MDGs?, PRDE Working Paper 2, Poverty Reduction in Difficult Environments Team, Policy Division, UK Department for International Development, London.

Chowdhury, A. (2009). 'Growth Oriented Macroeconomic Policies for Small-Island Economies: Lessons from Singapore', (In Naudé, W, A.U. Santos-Paulino and M. McGillivray eds. Vulnerability in Developing Countries. Tokyo and New York: UNU Press. Pp. 262-288.)

McGillivray, M. (2006), Aid Allocation and Fragile States, UNU-WIDER Discussion Paper No. 2006/01, Helsinki, Finland.

Feeny, S. and M. McGillivray (2009), “Aid Allocation to Fragile States: Absorptive Capacity Constraints", Journal of International Development, Vol. 21, Issue 5, pp. $618-632$. 
Heger, M.P., Julca, A. and Paddison, O. (2009). 'Vulnerability of Small-Island Economies: The Impact of Natural Disasters in the Caribbean', (In Naudé, W, A.U. Santos-Paulino and M. McGillivray eds. Vulnerability in Developing Countries. Tokyo and New York: UNU Press. Pp. 215-248.)

McGillivray, M., W. Naudé and A.U. Santos-Paulino (2008), Small island states development challenges: introduction, Journal of International Development, Volume: 20(4), May, pp. 481-485.

Naudé, W., A.U. Santos-Paulino and M. McGillivray, (2009a). Vulnerability in Developing Countries. Tokyo and New York: UNU Press.

Naudé, W, A.U. Santos-Paulino, A. and M. McGillivray, (2009b). 'Measuring Vulnerability. An Overview and Introduction', Oxford Development Studies, Sept. 37 (3): 183-191.

OECD (2008), Development Aid at Glance, OECD: Paris.

World Bank (2009a), World Development Indicators, Washington DC: World Bank.

World Bank (2009b), IDA Resource Allocation Index 2008, Washington DC: World Bank.

United Office of the High Representative for the Least Developed Countries (UN) (2009), Landlocked Developing Countries and Small Island Developing States, United New York: United Nations.

United Nations Development Programme (UNDP) (2009), Human Development Report 2009, Palgrave-Macmillan, New York. 
Appendix

Table A1: Countries Classified as Small Island Developing States

\begin{tabular}{lll}
\hline Caribbean & Pacific & Other \\
\hline Anguilla & American Samoa & Bahrain \\
Antigua and Barbuda & Cook Islands & Cape Verde \\
Aruba & Federated States of Micronesia & Comoros \\
Bahamas & Fiji & Guinea-Bissau \\
Barbados & French Polynesia & Maldives \\
Belize & Guam & Mauritius \\
British Virgin Islands & Kiribati & São Tomé and Principe \\
Cuba & Marshall Islands & Seychelles \\
Dominica & Nauru & Singapore \\
Dominican Republic & New Caledonia & Timor-Leste \\
Grenada & Niue & \\
Guyana & Northern Mariana Islands & \\
Haiti & Palau & \\
Jamaica & Papua New Guinea & \\
Montserrat & Samoa & \\
Netherlands Antilles & Solomon Islands & \\
Puerto Rico & Tonga & \\
Saint Kitts and Nevis & Tuvalu & \\
Saint Lucia & Vanuatu & \\
Saint Vincent \& the Grenadines & & \\
Suriname & & \\
Trinidad and Tobago & & \\
United States Virgin Islands & & \\
\hline
\end{tabular}

Source: UN (2009).

Note: We use in this paper the UN (2009) classification for Small Island Developing States. See also see www.un.org/special-rep/ohrlls/sid/list.htm. Not all SIDS are strictly speaking islands, as the inclusion of Guinea-Bissau for instance in the above list illustrates. 
Table A2: Economic Indicators in Selected Small Island Developing States, 2006

\begin{tabular}{|c|c|c|c|c|c|c|c|}
\hline & \multirow[b]{2}{*}{ Population } & \multirow{2}{*}{$\begin{array}{c}\text { Area } \\
\text { (Sq. Km.) }\end{array}$} & \multirow{2}{*}{$\begin{array}{l}\text { GDP per capita } \\
\text { (\$US million, } \\
2000 \text { prices) }\end{array}$} & \multicolumn{4}{|c|}{ Trade (\% GDP) } \\
\hline & & & & Total & Services & $\begin{array}{c}\text { Exports } \\
\text { (goods \& services) }\end{array}$ & Agriculture \\
\hline \multicolumn{8}{|l|}{ Africa } \\
\hline Cape Verde & 530,269 & 4,030 & $1,447.0$ & 75.0 & 58.9 & 19.9 & 8.6 \\
\hline Comoros* & 628,410 & 1,861 & 369.3 & 51.3 &.. & 2.7 & 12.6 \\
\hline Guinea-Bissau* & $1,694,653$ & 36,120 & 130.1 & 89.0 &.. & 42.6 & 63.6 \\
\hline Maldives* & 305,340 & 300 & $3,244.2$ & .. & 84.9 & .. & .. \\
\hline Mauritius & $1,26,692$ & 2,040 & $4,709.2$ & 132.9 & 55.3 & 61.8 & 5.3 \\
\hline Sao Tome \& Principe* & 158,013 & 960 & .. & .. & 15.8 & .. & .. \\
\hline Seychelles & 85,032 & 460 & $7,408.3$ & 316.7 & 106.4 & 136.4 & 3.0 \\
\hline \multicolumn{8}{|l|}{ Asia and Pacific } \\
\hline Fiji & 834,278 & 18,270 & $2,202.0$ & 113.4 &.. & 48.9 & 15.1 \\
\hline Kiribati* $^{*}$ & 95,067 & 810 & 486.7 &.. &.. & .. &.. \\
\hline Marshall Islands & 58,316 & 180 & $2,282.5$ &.. & .. &.. &.. \\
\hline Micronesia & 110,961 & 700 & $1,850.7$ &.. & .. &.. &.. \\
\hline Palau & 20,162 & 460 & $6,701.8$ & 131.8 & .. & 67.8 & 3.5 \\
\hline Papua New Guinea & $6,324,097$ & 462,840 & 656.1 & 157.5 & .. & 89.5 & 35.5 \\
\hline Samoa* & 181,293 & 2,840 & $1,712.6$ &.. & 37.0 &.. & 11.6 \\
\hline Solomon Islands* & 495,362 & 28,900 & 763.8 &.. &.. &.. & 33.5 \\
\hline Singapore & $4,588,600$ & 699 & $28,964.2$ & 433.0 & 88.2 & 230.9 & 0.1 \\
\hline Timor Leste & $1,061,129$ & 14,870 & 300.6 &.. &.. &.. &.. \\
\hline Tonga & 102,214 & 750 & $1,666.4$ &.. & 33.7 &.. & 27.5 \\
\hline Vanuatu & 225,898 & 12,190 & $1,275.0$ &.. & 57.9 &.. &.. \\
\hline \multicolumn{8}{|l|}{ Caribbean } \\
\hline Antigua \& Barbuda & 84,814 & 440 & $10,753.9$ &.. & .. & .. &.. \\
\hline Bahamas & 331,140 & 13,880 & $17,353.8$ &.. & 63.6 &.. &.. \\
\hline Barbados & 293,942 & 430 &.. &.. & .. & .. &.. \\
\hline Belize & 303,991 & 22,970 & $3,769.2$ & 121.6 & 44.3 & 59.9 & 12.3 \\
\hline Cuba & $11,257,013$ & 110,860 & .. &.. &.. &.. &.. \\
\hline Dominica & 72,793 & 750 &.. &.. &.. &.. &.. \\
\hline Dominican Republic & $9,725,569$ & 48,730 & $2,889.3$ & 75.9 & 18.0 & 34.5 & 12.0 \\
\hline Grenada & 105,668 & 340 & $4,127.1$ & .. & 42.3 &.. &.. \\
\hline Guyana & 738,548 & 214,970 & $1,062.1$ &.. & 41.2 & .. & .. \\
\hline Haiti* & $9,611,554$ & 27,750 & 411.3 & 45.4 & 13.5 & 11.0 &.. \\
\hline Jamaica & $2,675,800$ & 10,990 & $3,091.1$ &.. & 43.4 &.. &.. \\
\hline St. Kitts and Nevis & 48,790 & 260 & $8,660.3$ & 52.2 &.. &.. &.. \\
\hline St. Lucia & 167,975 & 620 & $4,791.8$ &.. & 53.4 &.. &.. \\
\hline St.Vincent \& the Grenadines & 120,325 & 390 & $3,733.9$ &.. & 50.6 &.. &.. \\
\hline Suriname & 457,686 & 163,270 & $2,875.8$ & .. & 25.1 & .. &.. \\
\hline Trinidad and Tobago & $1,333,050$ & 5,130 & $10,657.2$ & 94.7 &.. & 57.6 & 0.4 \\
\hline
\end{tabular}

Source: World Bank (2009a). Only UN member countries are included in table and * denotes LCD status.

\footnotetext{
${ }^{1}$ Appendix Table A1 and A2 provide a listing of all current SIDS and data on economic and demographic data, respectively.

${ }^{2}$ Data in all Figures shown in this paper are taken from World Bank (2009a).
} 